\title{
Rancang Bangun Electronic Nose untuk Mendeteksi Tingkat Kebusukan Ikan Air Tawar
}

\author{
Chrisal Aji Lintang**1 ${ }^{1}$, Triyogatama Wahyu Widodo ${ }^{2}$, Danang Lelono ${ }^{3}$ \\ ${ }^{1}$ Program Studi Elektronika dan Instrumentasi, JIKE, FMIPA, UGM, Yogyakarta \\ ${ }^{2,3}$ Jurusan Ilmu Komputer dan Elektronika, FMIPA UGM, Yogyakarta \\ e-mail: * ${ }^{1}$ chriisaal@gmail.com, ${ }^{2}$ yogatama@ugm.ac.id, ${ }^{3}$ danang@ugm.ac.id
}

\begin{abstract}
Abstrak
Ikan merupakan makanan yang dikonsumsi di seluruh belahan dunia. Saat ikan mati, saat itu juga kesegaran ikan mulai berkurang sampai ikan itu tidak layak dikonsumsi. Tingkat kesegaran daging ikan bisa dibedakan melalui bau yang dihasilkan. Telah dirancang dan diimplementasikan sebuah alat hidung elektronik yang dapat mendeteksi aroma ikan air tawar.

Untuk dapat mendeteksi aroma ikan air tawar, sistem electronic nose yang dirancang mengalirkan udara dari ruang sampel ke ruang sensor menggunakan kipas. Saat proses pengambilan aroma sampel (odor on) kipas akan mengalirkan udara yang berisi aroma sampel dari ruang sampel ke ruang sensor, dan udara luar dialirkan ke ruang sensor pada saat odor off. Stimulus aroma yang ditangkap oleh larik sensor berupa respon sinyal di ekstraksi dengan metode integral sehingga didapat pola aroma sampel digital (digital fingerprint). Pola ini kemudian dianalisis dengan metode PCA (Principal Component Analysis) untuk menentukan pola aroma ikan air tawar.

Hasil penelitian ini menunjukkan bahwa sistem electronic nose dapat mendeteksi aroma ikan air tawar dengan persentase variansi dua komponen utama sebesar 98,7\% (bawal), 98,8\% (lele), dan 99,5\% (nila). Sensor yang memberikan respon tinggi pada setiap sampel adalah sensor TGS 2620 dan TGS 2600. Sensor TGS 822 memberikan respon tinggi pada ikan saat sudah tidak layak konsumsi.
\end{abstract}

Kata kunci-Ikan, hidung elektronik, larik sensor, Principal Component Analysis (PCA).

When fish die, fish freshness start to reduce gradually until cannot be eaten anymore. Properness of fish meat can be identified by odor that come out from fish itself. An instrument called electronic nose that can detect pattern of fish odor has been designed and implemented in this research.

To be able to detect scent of freshwater fish, electronic nose will drain the air from sample chamber to sensor chamber using fan. When taking sample aroma, fan will drain air that contain sample scent from sample chamber to sensor chamber, and air from the outside flowed into sensor chamber when odor off. Scent stimulus captured by sensor array in form of signal response will be extracted with integral method so that the digital fingerprint from samples can be obtained. This pattern then analyzed by PCA (Principal Component Analysis) to determine patterns of freshwater fish odor.

Result from this study indicated that electronic nose system can detect scent of freshwater fish with percentage variance of two major components are 98.7\% (pomfret), $98.8 \%$ (catfish), and 99.5\% (tilapia). Sensors that give high response in each samples is TGS 2620, and TGS 2600. TGS 822 give high response when fish is rotting.

Keywords - Fish, electronic nose, array sensor, Principal Component Analysis (PCA). 


\section{PENDAHULUAN}

$\mathrm{D}$ lam kegiatan perikanan air tawar, disamping banyak keberhasilannya tidak jarang pula kegagalannya. Beberapa faktor yang mempengaruhi kegagalan diantaranya adalah penanganan ikan pasca panen. Kelemahan di dalam penanganan ikan pasca panen ini salah satunya adalah kurang baiknya penyimpanan ikan sehingga menyebabkan ikan cepat membusuk [1]. Proses membusuk ikan disebabkan karena pada saat ikan mati maka saat itu pula kesegaran ikan mulai berkurang dan berkelanjutan sampai ikan itu membusuk dalam beberapa waktu. Proses pembusukan pada ikan saat masih segar sampai ikan mulai membusuk terjadi hanya dalam beberapa jam saja[1].

Pada saat terjadi proses pembusukan, ikan menghasilkan aroma yang tidak sedap. Aroma ini dipengaruhi oleh senyawa-senyawa kimia yang sangat kompleks. Salah satu senyawa yang dikeluarkan oleh aroma tak sedap ini adalah senyawa trimethylamine. Senyawa ini merupakan senyawa organik yang mengandung atom nitrogen, karbon, dan hidrogen dengan rumus umum NR3. Pada senyawa amine, $\mathrm{R}$ dapat berupa gugus hidrokarbon atau hanya berupa atom hidrogen[2]. Oleh karena kompleksnya kandungan senyawa pada aroma tak sedap ikan ini, maka untuk mendeteksinya selama ini digunakan hidung manusia sebagai pembau, disamping pendeteksian dengan melihat bentuk fisik ikan. Namun pada kenyataannya penciuman manusia memiliki kelemahan terutama pada standarisasi karena penilaian yang bersifat subyektif pada setiap manusia[3]. Untuk mengatasi permasalahan tersebut dapat digunakan analitik kimia seperti gas kromatografi, tetapi penelitian ini memerlukan biaya mahal dan membutuhkan tenaga ahli untuk dapat mendeteksi kandungan senyawa didalamnya. Oleh karena itu untuk mendeteksi kesegaran ikan ini diperlukan sebuah instrumen yang dapat mendeteksi aroma ikan berbasis larik sensor.

Electronic nose (e-nose) adalah sebuah instrumen yang kerjanya meniru prinsip kerja indra penciuman [4]. Electronic nose terdiri dari larik sensor (array sensor) gas sebagai pengganti reseptor penciuman yang berfungsi untuk mendeteksi bau atau aroma. Aroma yang dideteksi oleh beberapa sensor gas ini kemudian akan membentuk suatu pola tertentu. Pola ini kemudian akan dikenali menggunakan sistem pengenalan pola. Saat ini, e-nose digunakan untuk aplikasi kontrol kualitas dalam industri makanan, minuman, kosmetik, bioteknologi, pengobatan, dan perlindungan lingkungan [5]. Pada industri makanan, e-nose telah digunakan untuk mendeteksi kesegaran makanan seperti daging sapi, daging babi, dan tahu. Oleh karena ikan juga memiliki keterbatasan dalam hal kesegaran, dan kesegaran ikan sangat berpengaruh pada aroma, maka perlu dilakukan penelitian mengenai kesegaran ikan berdasarkan aroma menggunakan sensor gas.

\section{METODE PENELITIAN}

\subsection{Analisa}

Prinsip kerja dari electronic nose adalah meniru tindakan hidung manusia dengan mengenali pola respon terhadap aroma. Aroma terdiri dari molekul yang masing-masing memiliki ukuran dan bentuk tertentu. Reseptor menangkap suatu molekul kemudian mengirimkan sinyal ke otak dan otak mengidentifikasi aroma yang terkait dengan molekul tersebut. Tujuan pengidentifikasian tersebut adalah mengenali pola aroma sederhana ataupun kompleks. Oleh karena itu, keluaran dari hidung elektronik dapat menjadi identitas atau sifat karakteristik sampel sehingga memungkinkan adanya sifat karakteristik aroma [6].

E-nose terdiri dari tiga komponen fungsional utama yang beroperasi secara serial pada sampel aroma yaitu ruang sampel (sample chamber), susunan sensor (sensor array), dan sistem akuisisi data [6]. Sampel yang akan diuji diletakkan pada ruang sampel. Aroma sampel dialirkan ke ruang susunan sensor yang terdapat pada ruang sensor menggunakan sistem aliran udara. Sensor gas disusun menjadi suatu susunan sensor untuk merespon senyawa kimia tertentu pada

IJEIS Vol. 6, No. 2, October 2016 : 129 - 140 
sampel. Respon tersebut berbentuk sinyal analog yang kemudian ditangkap oleh ADC (Analog to Digital Converter) sehingga dapat dibaca oleh komputer.

Ikan air tawar merupakan bahan pangan yang banyak mengandung protein. Selama penyimpanan, terjadi degradasi protein menjadi senyawa-senyawa yang lebih sederhana seperti trimethylamine dan amonia. Senyawa-senyawa ini akan mengeluarkan aroma khas yang merupakan aroma ikan busuk. Senyawa trimethylamine adalah senyawa organik yang tersusun dari atom nitrogen, karbon, dan hidrogen. Berdasarkan hal itu, pada penelitian ini digunakan sensor-sensor yang dapat mendeteksi senyawa organik, dan atom-atom yang terkandung pada senyawa trimethylamine.

Pada e-nose terdapat dua buah keadaan, yaitu sensing (odor on) dan flushing (odor off). Pada keadaan odor on, udara dialirkan dari ruang sampel ke ruang sensor sehingga aroma sampel dapat terdeteksi oleh sensor. Sedangkan pada keadaan odor off, udara dari ruang sensor akan dialirkan keluar $e$-nose, sehingga aroma yang berada pada ruang sensor akan ikut keluar yang mengakibatkan sensor pada larik sensor tidak mencium aroma sampel [4].

\subsection{Perancangan Sistem}

Sistem yang dibuat pada penelitian ini dirancang agar deret sensor TGS yang digunakan dapat mendeteksi karakteristik dari pola bau yang dihasilkan oleh ikan air tawar. Rancangan diagram blok sistem dapat dilihat pada Gambar 1.

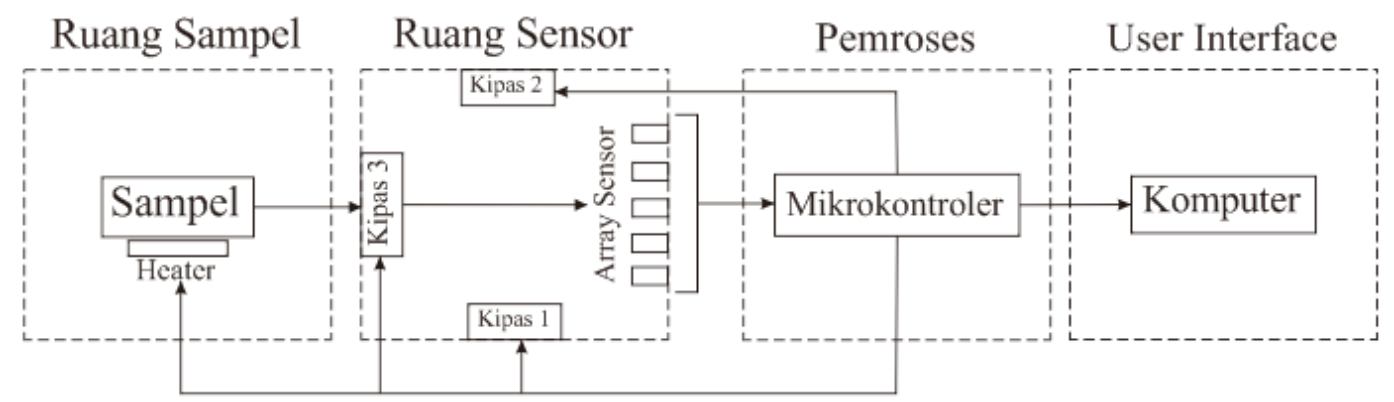

Gambar 1 Diagram blok sistem electronic nose

Gambar 1 menjelaskan bahwa sampel diidentifikasi menggunakan beberapa sensor gas yang terdapat pada array sensor dengan karakteristik sensor yang berbeda-beda. Sensor diletakkan pada ruang sensor dan dipanaskan pada suhu tertentu. Aroma yang dihasilkan oleh sampel kemudian dialirkan ke ruang sensor oleh kipas 3 dan akan dideteksi oleh sensor. Sensor kemudian akan menghasilkan sinyal analog yang dikirimkan ke mikrokontroler. ADC pada mikrokontroler akan merubah sinyal analog yang dikirimkan dari sensor menjadi sinyal digital. Mikrokontroler kemudian akan membaca nilai tegangan output dari sensor. Data lalu dikirimkan melalui USB Serial ke komputer. Selanjutnya data yang diterima akan ditampilkan dalam bentuk grafik pada perangkat komputer menggunakan aplikasi LabVIEW. Grafik data yang ditampilkan merupakan nilai tegangan yang diterima mikrokontroler dari sensor. Data berupa nilai tegangan kemudian akan disimpan pada aplikasi Microsoft Excel yang nantinya akan dilakukan analisis untuk melihat pola aroma ikan air tawar.

Sensor yang digunakan pada electronic nose tersusun atas 5 buah sensor TGS yang mempunyai karakteristik yang berbeda. Beberapa faktor dan parameter harus dipertimbangkan dalam pemilihan komponen sistem, terutama pada pemilihan sensor. Amina yang dikenal sebagai bau ikan atau daging hewan yang membusuk, adalah senyawa organik yang mengandung nitrogen dan memiliki rumus umum NR3. Pada amina, R dapat berupa gugus hidrokarbon atau hanya atom hidrogen. Salah satu jenis amina yang merupakan bau ikan busuk adalah Trimetilamina. Trimetilamina merupakan senyawa yang terdiri dari oksigen, nitrogen, dan senyawa hidrokarbon. Sensor TGS yang digunakan pada penelitian ini yaitu TGS 2620, TGS 813, TGS 822, TGS 2600, dan TGS 2602. 


\subsection{Prosedur dan Pengumpulan Data}

\subsubsection{Preparasi sampel}

Penelitian ini menggunakan 3 sampel ikan air tawar (nila, lele, dan bawal). Setiap sampel ikan dipotong dan disimpan pada suhu ruangan $\pm 27^{\circ} \mathrm{C}$. Sampel diuji setiap dua setengah jam sekali setelah disimpan selama lima jam sampai sampel mengeluarkan bau tidak enak yang menandakan sampel sudah tidak boleh dikonsumsi.

\subsubsection{Pengambilan dan pengolahan data}

Segera setelah dipotong, daging ikan diuji menggunakan electronic nose untuk mengetahui pola aroma ikan yang masih segar. Setelah dilakukan pengujian, sampel diletakkan dalam wadah dan disimpan pada suhu ruangan. Sebelum dilakukan pengujian, dilakukan pemanasan sensor selama 30 menit agar semua sensor dalam keadaan stabil. Sampel diletakkan pada ruang sampel dan ruang sampel ditutup. Odor on diatur pada waktu 180 detik dan odor off diatur pada 120 detik. Pada setiap pengujian, dilakukan 10 kali siklus odor off dan odor on pada sampel.

\subsubsection{Normalisasi baseline}

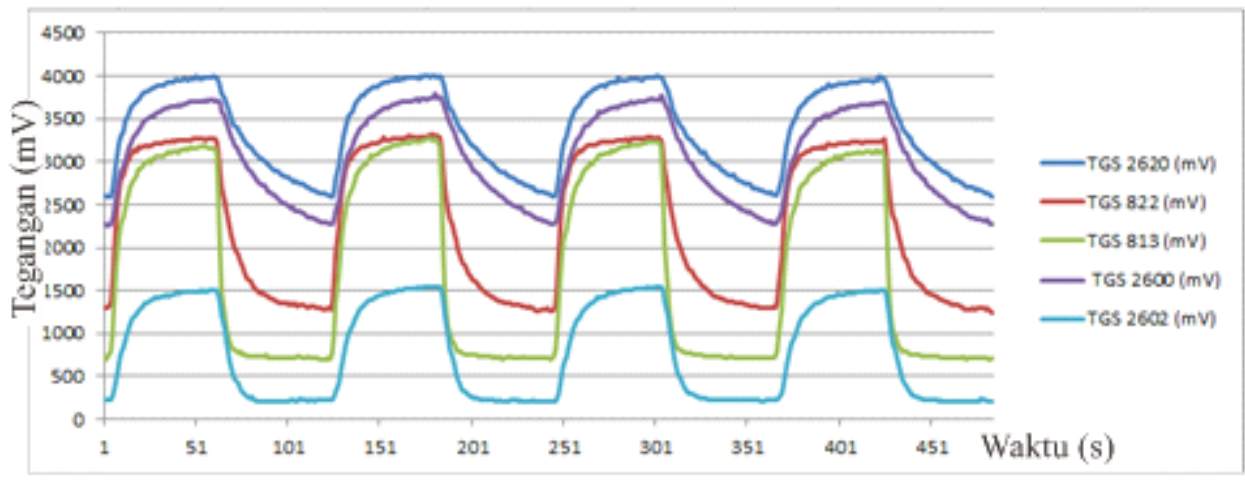

Gambar 2 Pengambilan data

Gambar 2 merupakan salah satu hasil pengambilan data sebelum dilakukan normalisasi baseline. Proses pengolahan data yang pertama kali dilakukan adalah normalisasi baseline. Baseline adalah respons sensor terhadap zat referensi contohnya udara bersih atau gas nitrogen [7]. Nilai baseline diambil sebelum pengambilan data untuk sampel uji. Nilai baseline diharapkan sama untuk proses pengidentifikasian lebih lanjut, namun dalam kondisi nyata hal ini sulit dicapai. Setiap sensor memiliki karakteristik yang berbeda-beda, dan juga nilai baseline yang berbeda pula. Proses normalisasi baseline ini digunakan untuk menyamakan baseline setiap sensor agar lebih mudah dilakukan pengolahan data selanjutnya. Normalisasi baseline dilakukan dengan cara mengurangi setiap nilai data dengan nilai pertama, seperti pada persamaan (1).

$$
Y n=Y n-Y 1
$$

Dimana Yn adalah nilai data sensor dan $Y 1$ adalah nilai pertama atau terendah dari data yang didapat. Gambar 3 merupakan data setelah dilakukan normalisasi baseline. Pada Gambar 3 terlihat bahwa data setiap sensor memiliki nilai baseline yang sama. 


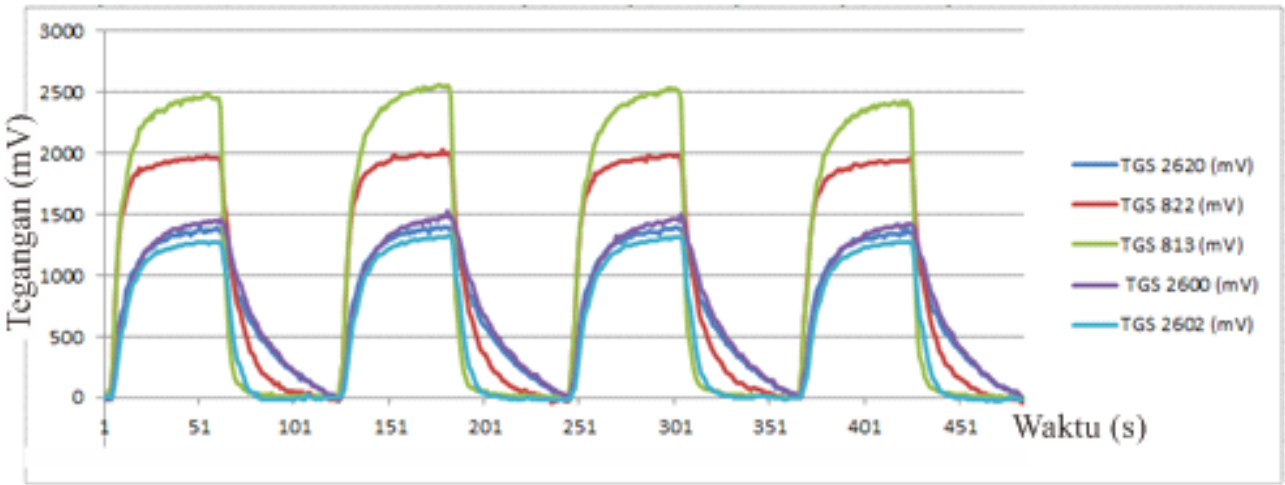

Gambar 3 Normalisasi baseline

\subsubsection{Ekstraksi ciri}

Setelah dilakukan normalisasi baseline, dilakukan ekstraksi ciri. Ekstraksi ciri pada electronic nose adalah proses untuk mengekstraksi informasi penting dan relevan dari sinyal sensor yang dapat mewakili ciri respon sensor secara keseluruhan [7]. Ekastraksi ciri dapat dilakukan dengan menghitung luasan kurva respon sensor pada bagian odor on pada satu siklus odor on-odor off [8].

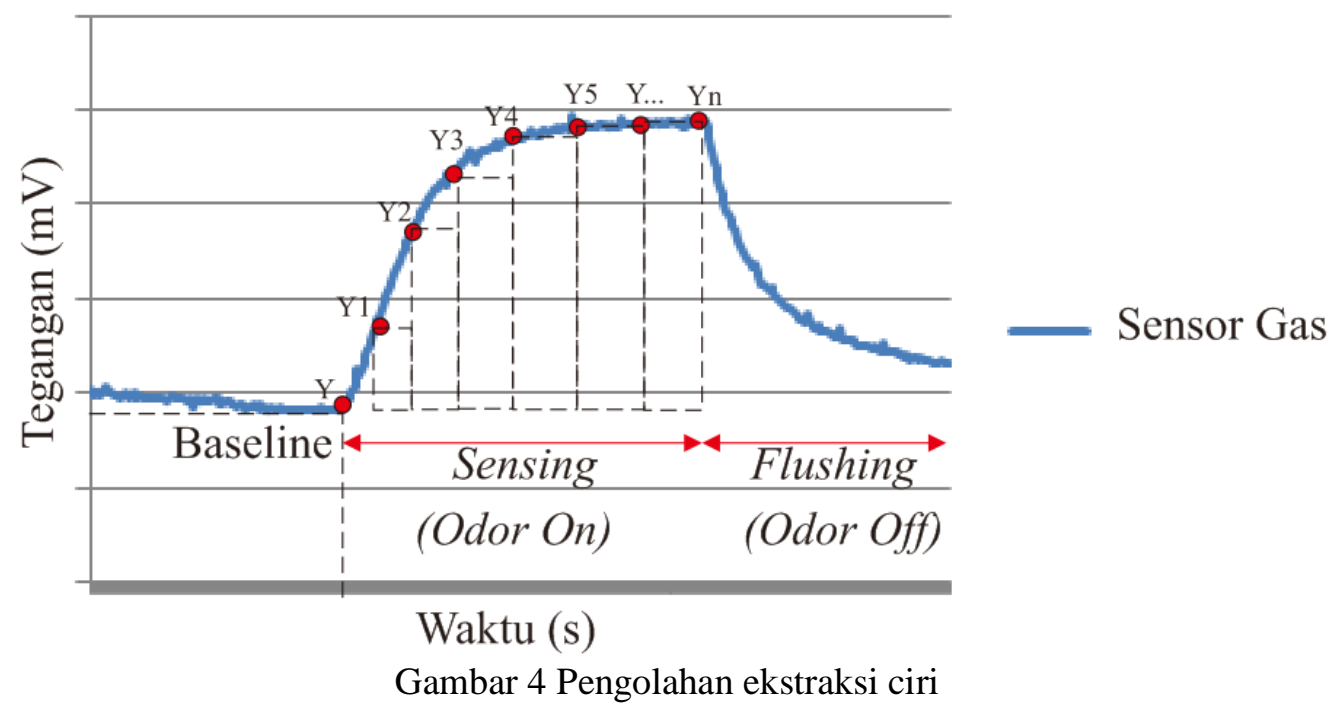

Gambar 4 merupakan gambar pengolahan ekstraksi ciri. Ekstraksi ciri didapatkan dengan menghitung nilai luasan respon sensor pada saat odor on. Persamaan (2) dibawah ini digunakan untuk mencari nilai ekstraksi ciri untuk satu kali siklus odor on.

$$
L=\sum_{i=1}^{n} Y i
$$

Dimana L merupakan nilai ekstraksi ciri, Yi merupakan data nilai sensor, dan $n$ merupakan jumlah data. Pada setiap pengujian, dilakukan sepuluh kali pengambilan data sehingga akan didapat sepuluh buah nilai ekstraksi ciri.

\subsubsection{Ripitabilitas electronic nose}

Selanjutnya dilakukan pengujian ripitabilitas. Pengujian ripitabilitas adalah pengujian untuk mengetahui tingkat presisi respon sensor $e$-nose dalam melakukan pengulangan pengujian sampel [7]. Ripitabilitas e-nose didapatkan dengan menghitung nilai standar deviasi relatif (RSD) dari nilai ciri yang telah diekstraksi. Semakin kecil nilai RSD maka semakin tinggi ripitabilitasnya. Nilai RSD dari masing-masing sensor dihitung menggunakan persamaan (3). 


$$
R S D=\frac{\sigma}{\mu} X 100 \%
$$

Dimana $\boldsymbol{\sigma}=$ standar deviasi dan $\mu=$ nilai rata-rata ciri. Nilai RSD direpresentasikan dalam bentuk persen.

\subsubsection{PCA (Principal Component Analysis)}

Principal Component Analysis (PCA) adalah suatu metode yang melibatkan prosedur matematika yang mengubah dan mentransformasikan sejumlah besar variabel yang berkorelasi menjadi sejumlah kecil variabel yang tidak berkorelasi, tanpa menghilangkan informasi penting di dalamnya. Prosedur PCA pada dasarnya adalah bertujuan untuk menyederhanakan variabel yang diamati dengan cara menyusutkan (mereduksi) dimensinya. Hal ini dilakukan dengan cara menghilangkan korelasi diantara variabel bebas melalui transformasi variabel bebas asal ke variabel baru yang tidak berkorelasi sama sekali atau yang biasa disebut dengan principal component. PCA mentransformasikan data ke dalam koordinat baru, di mana koordinat pertama merupakan Principal Component pertama yang diperoleh dari eigen value terbesar pertama, koordinat kedua merupakan Principal Component kedua yang diperoleh dari eigen value terbesar kedua dan seterusnya. Setelah beberapa komponen hasil PCA yang bebas multikolinearitas diperoleh, maka komponen-komponen tersebut menjadi variabel bebas baru yang akan diregresikan atau dianalisa pengaruhnya terhadap variabel tak bebas dengan menggunakan analisis regresi [9].

\section{HASIL DAN PEMBAHASAN}

\subsection{Pengujian Sampel}

Pengujian yang dilakukan merupakan pengujian terhadap ikan bawal, lele, dan nila. Data yang diambil berupa nilai tegangan $(\mathrm{mV})$ masing-masing sensor yang kemudian disimpan dalam file dan diolah dengan Microsoft Excel. Segera setelah dipotong, daging ikan diuji menggunakan electronic nose untuk mengetahui pola aroma ikan yang masih segar. Ikan air tawar kemudian disimpan pada ruangan bersuhu kurang lebih $27^{\circ} \mathrm{C}$. Ikan diuji pada saat telah disimpan selama 5 jam, 7,5 jam, 10 jam, dan seterusnya sampai ikan sudah mengeluarkan bau tidak sedap. Gambar 5 merupakan grafik respon sensor terhadap ikan bawal dalam satu kali siklus odor on dan odor off setelah dilakukan normalisasi data.

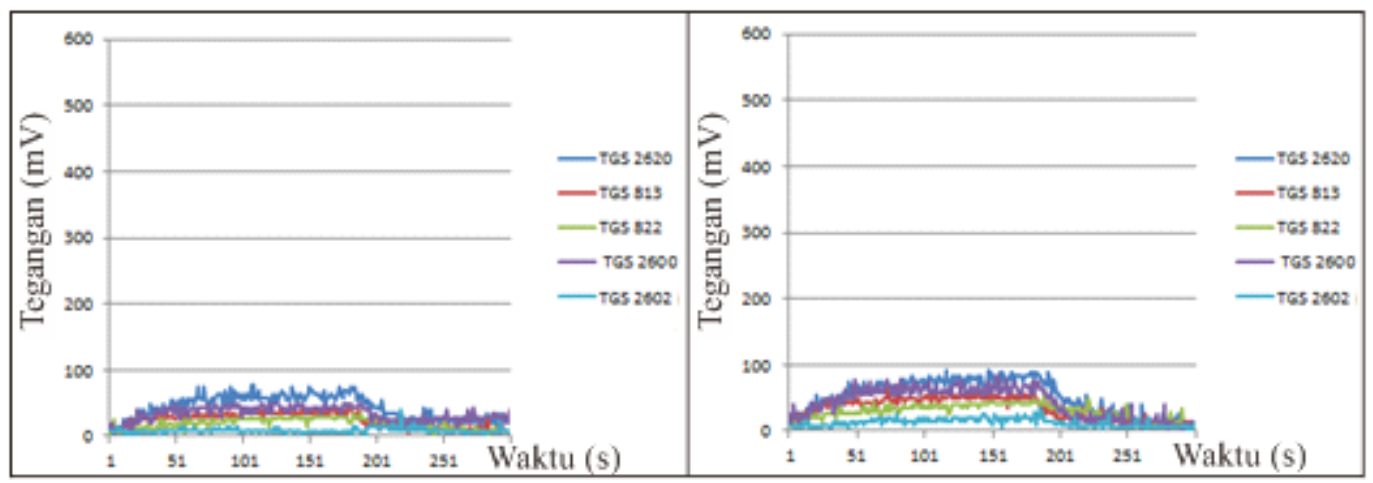

a

b

IJEIS Vol. 6, No. 2, October 2016 : 129 - 140 

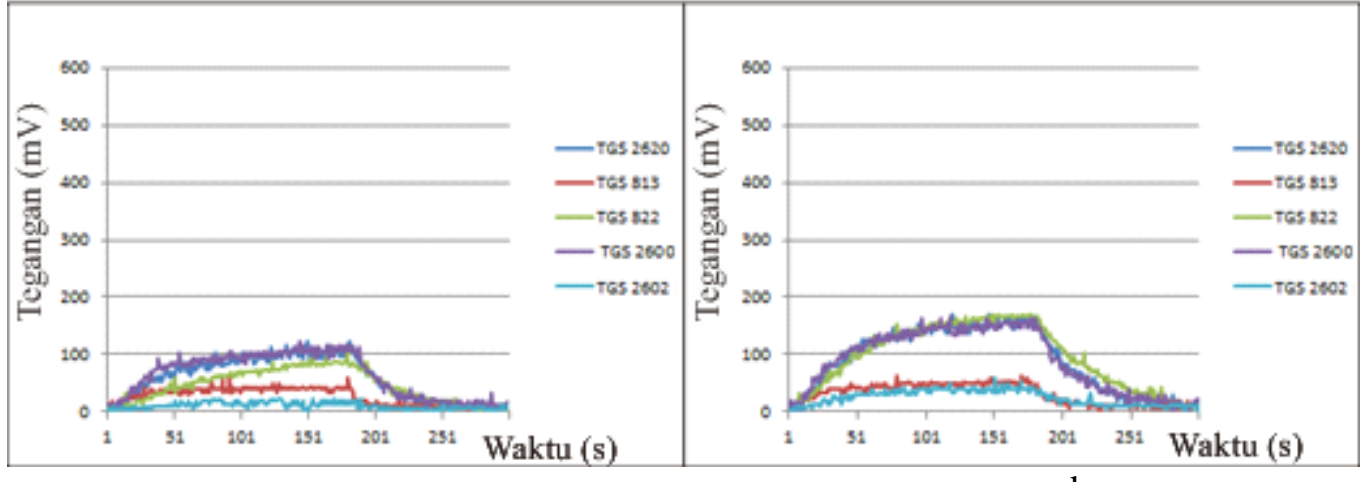

$\mathrm{c}$

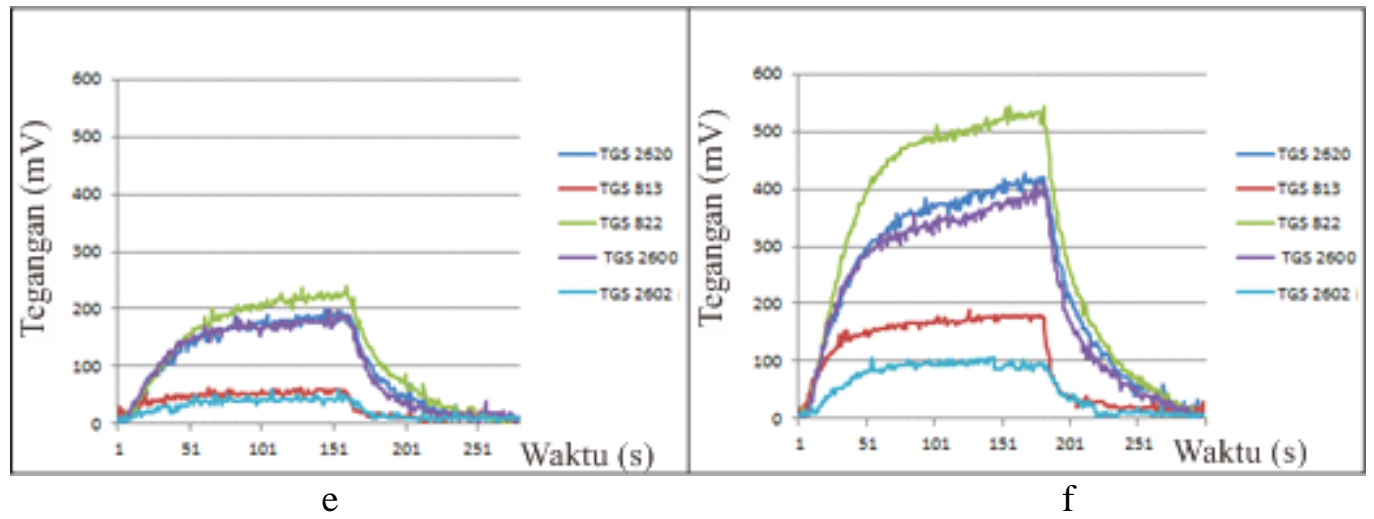

Gambar 5 Grafik respon sensor pada ikan bawal (a) 0 jam, (b) 5 jam,

(c) 7,5 jam, (d) $10 \mathrm{jam}$, (e) 12,5 jam (f) 24 jam

Dari grafik respon sensor terlihat bahwa semakin lama waktu penyimpanan ikan, semakin besar pula respon yang dihasilkan oleh sensor. Pada waktu penyimpanan 0 sampai 5 jam, daging ikan masih segar dan mengeluarkan bau yang lemah, sehingga respon sensor masih kecil. Pada penyimpanan 7,5 jam dan 10 jam, daging ikan mengeluarkan bau yang lebih kuat, hal ini dapat dilihat pada grafik bahwa nilai yang didapat lebih tinggi dari nilai pengambilan data sebelumnya. Pada penyimpanan 12,5 jam ikan bawal sudah mengeluarkan bau tidak sedap.

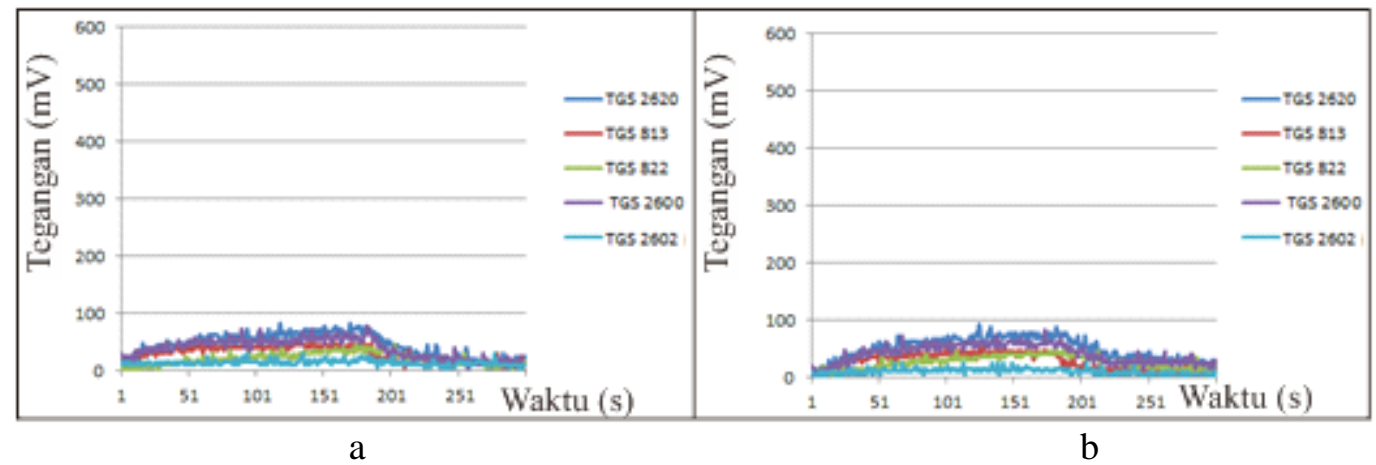




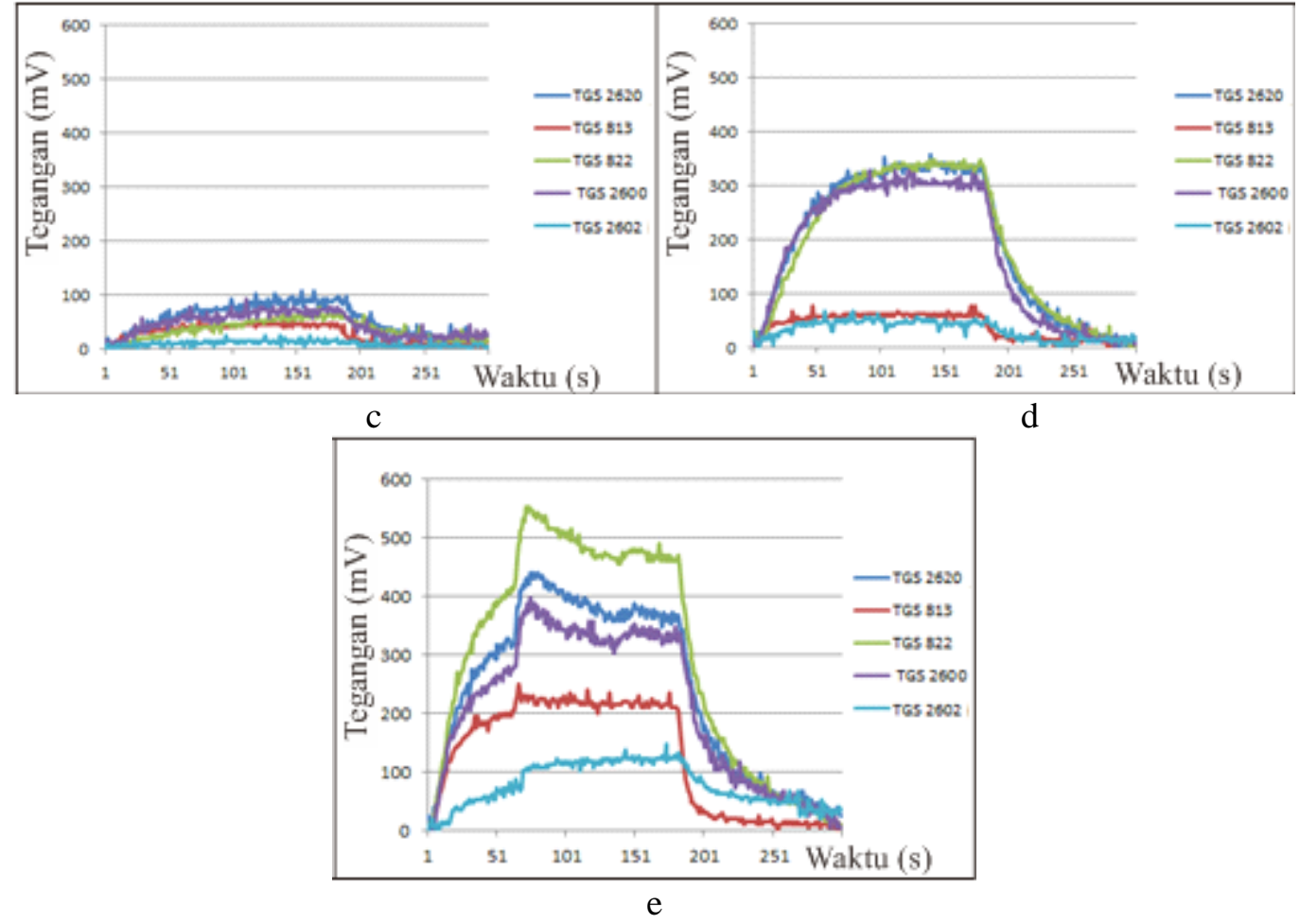

Gambar 7 Grafik respon sensor pada ikan lele (a) 0 jam, (b) 5 jam,

(c) 7,5 jam, (d) 10 jam, (e) 24 jam

Gambar 7 merupakan Grafik respon sensor pada pengujian sampel ikan lele. Terlihat pada gambar bahwa semakin lama waktu penyimpanan ikan, semakin besar pula respon yang dihasilkan oleh sensor. Tidak seperti pada bawal, Pada waktu penyimpanan 0 dan 5 jam, sensor sudah menunjukkan nilai yang cukup tinggi dibanding bawal. Tetapi, nilai respon pada waktu 0 jam dan 5 jam tidak berbeda jauh dengan nilai respon yang dihasilkan pada waktu 7,5 jam. Pada penyimpanan 10 jam, daging ikan lele sudah mengeluarkan bau tidak sedap, beberapa sensor yaitu sensor TGS 2620, TGS 822, dan TGS 2600 menghasilkan nilai respon yang tinggi. Hal ini berarti sensor-sensor tersebut sangat sensitif terhadap aroma tidak sedap yang ditimbulkan ikan lele. Hal ini juga dapat diartikan bahwa saat ikan lele masih baik dikonsumsi, aroma yang dihasilkan tidak begitu berbeda pada saat 0 jam, 5 jam, dan 7,5 jam, tetapi saat lele sudah tidak layak konsumsi yaitu pada penyimpanan 10 jam keatas, aroma yang dihasilkan sangat kuat sehingga respon sensor yang dihasilkan memiliki nilai yang jauh lebih tinggi dibanding saat ikan masih dapat dikonsumsi.

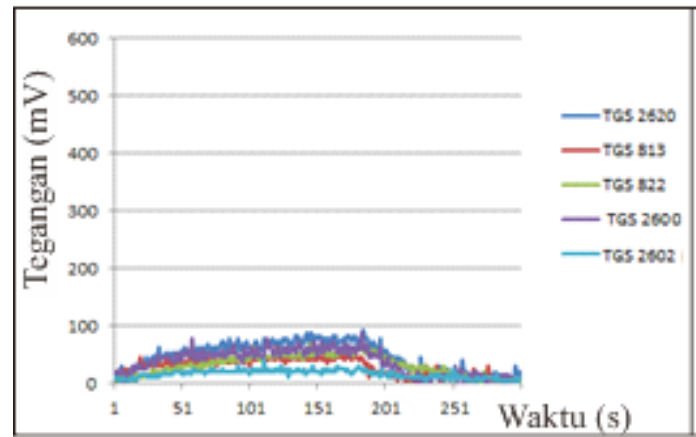

a

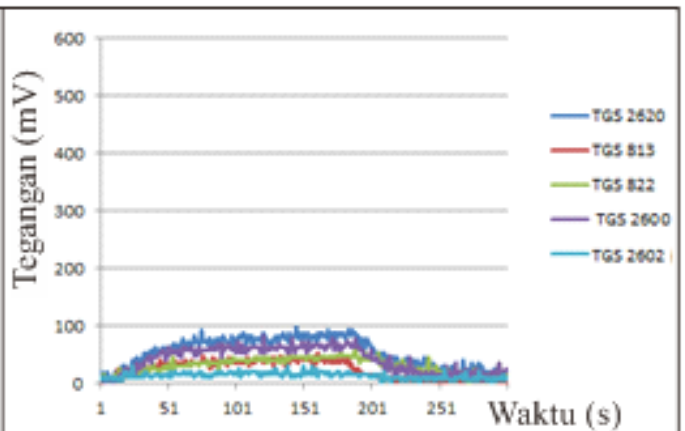

b

IJEIS Vol. 6, No. 2, October 2016 : $129-140$ 

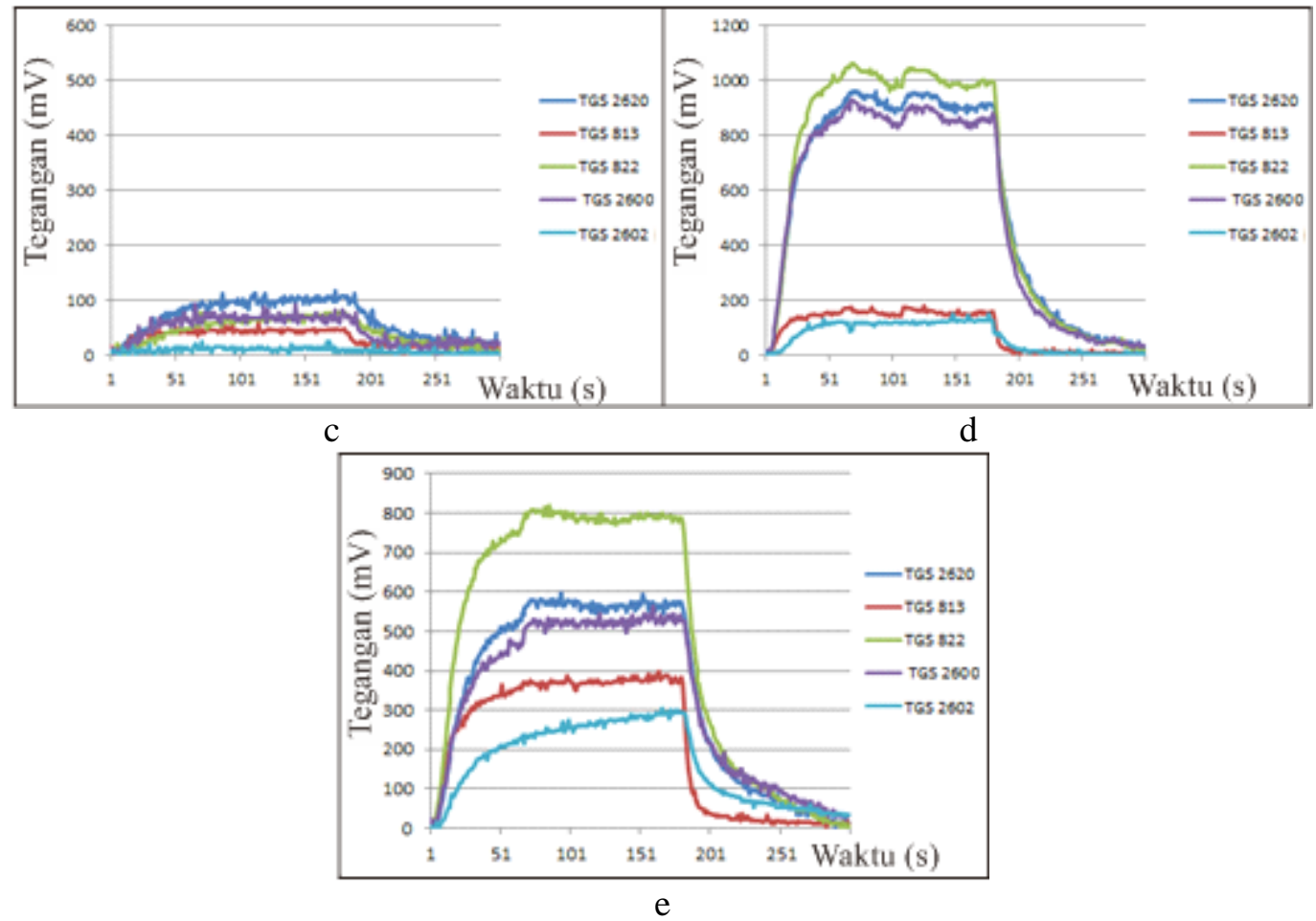

Gambar 8 Grafik respon sensor pada ikan nila (a) 0 jam, (b) 5 jam, (c) 7,5 jam, (d) $10 \mathrm{jam}$, (e) 24 jam

Gambar 8 adalah gambar respon sensor ikan nila. Seperti pada ikan lele, nilai respon pada waktu 0 jam dan 5 jam tidak berbeda jauh karena ikan masih segar. Respon sensor pada ikan nila penyimpanan 7,5 jam menunjukkan nilai yang sedikit lebih besar dari penyimpanan 5 jam. Pada penyimpanan 10 jam, daging ikan nila sudah mengeluarkan bau tidak sedap, beberapa sensor yaitu sensor TGS 2620, TGS 822, dan TGS 2600 menghasilkan nilai respon yang tinggi sama halnya seperti pada lele. Pada saat masih segar, ikan nila mengeluarkan aroma yang tidak begitu kuat, tetapi saat sudah membusuk, aroma yang dihasilkan sangat kuat sehingga respon sensor yang dihasilkan memiliki nilai yang jauh lebih tinggi dibanding saat ikan masih dapat dikonsumsi.

\subsection{Pengolahan Data Menggunakan PCA}

Analisis menggunakan PCA bertujuan untuk mendapatkan variabel baru yang lebih sederhana dan saling bebas dari variabel asli. Dalam PCA jumlah variabel yang besar dapat direduksi menjadi 2 principal component (PC). Kedua komponen utama tersebut dapat mewakilkan variabel semula tanpa menghilangkan banyak informasi yang terkandung dalam variabel semula. Pada PCA terdapat nilai eigenvalue yang merupakan nilai variansi principal component. Dalam penelitian ini, terdapat 5 variabel berupa output masing-masing sensor gas, yaitu TGS 2620, TGS 822, TGS 813, TGS 2600, dan TGS 2602. Variabel-variabel tersebut diseduksi menjadi 2 variabel baru yaitu first component (PC1) dan second component (PC2) dimana kedua variabel baru tersebut dapat menjelaskan persentase dari total variabilitas kelima variabel sebelumnya.

Pengolahan data menggunakan PCA dilakukan dengan memasukkan nilai ekstraksi ciri data, yaitu berupa nilai luasan dari respon sensor saat dalam keadaan odor on. Terdapat 10 kali siklus odor on yang terjadi dalam satu kali pengambilan data, sehingga akan ada 10 jumlah nilai ekstraksi ciri yang dimasukkan dalam PCA pada satu kali pengujian sampel. Hasil pengolahan data menggunakan PCA kemudian ditampilkan dalam bentuk grafik score plot untuk melihat persebaran data yang dihasilkan oleh sampel yang diuji. Gambar 9 merupakan grafik score plot pengujian sampel ikan air tawar. 


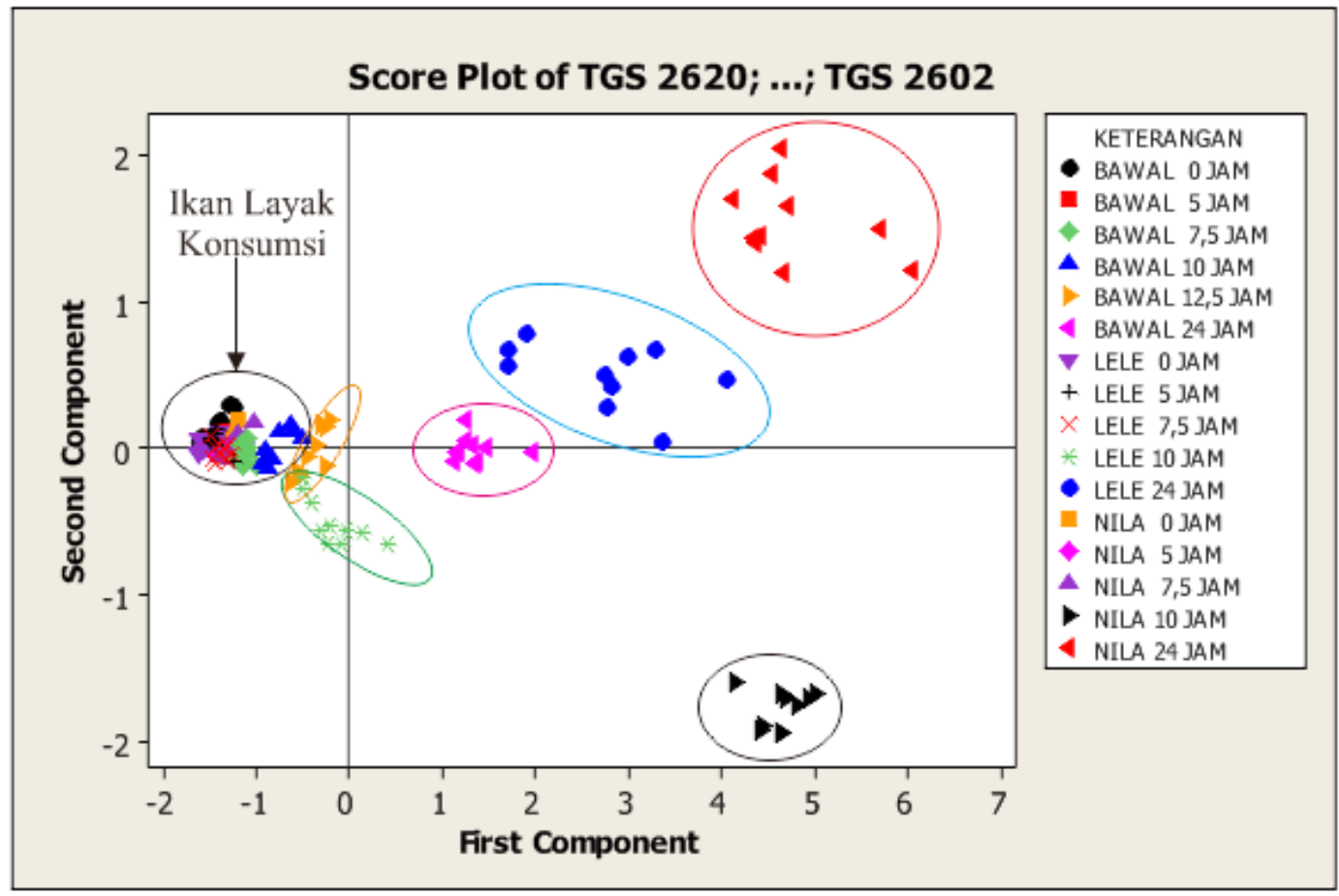

Gambar 9 Grafik score plot sampel ikan air tawar

Gambar 9 merupakan grafik score plot keseluruhan dari semua sampel yang diuji. Dari gambar terlihat bahwa aroma ikan yang masih layak konsumsi yaitu bawal penyimpanan $0-10$ jam, lele penyimpanan $0-7,5$ jam,dan nila penyimpanan $0-7,5$ jam mengumpul pada satu tempat. Sedangkan ikan yang sudah tidak layak konsumsi berkumpul pada tempat lain. Artinya metode PCA sudah dapat membedakan antara aroma sampel ikan layak konsumsi (segar) dan tidak (busuk). Tetapi untuk aroma ikan segar berdasarkan jenisnya menggunakan metode PCA masih sulit dibedakan karena pada grafik score plot terlihat bahwa data dari ikan layak konsumsi mengumpul di satu tempat dan memiliki perbedaan yang kecil. Hasil analisis PCA menunjukkan bahwa persentase variansi dua komponen utama sebesar 98,92\%.

\subsection{Pengujian Ripitabilitas}

Uji ripitabilitas adalah pengujian untuk mengetahui tingkat presisi respon sensor $e$ nose dalam melakukan pengulangan pengujian sampel. Ripitabilitas $e$-nose didapatkan dengan menghitung nilai standar deviasi relatif (RSD) dari nilai ciri yang telah diekstraksi menggunakan persamaan 3. Hasil penghitungan ripitabilitas masing-masing sensor $e$-nose ditunjukkan pada Tabel 1.

Pada Tabel 1 terlihat bahwa persentase RSD untuk sensor TGS 2620, TGS 823, TGS 833, dan TGS 2600 mempunyai rentang nilai dari 3,245\% sampai dengan 34,94\%. Nilai ripitabilitas terkecil (terbaik) yaitu 3,245\% dimiliki oleh sensor TGS 2620 pada pengujian ikan nila 10 jam, dan nilai ripitabilitas terbesar dihasilkan oleh sensor TGS 2600 pada pengujian ikan bawal 0 jam. Sedangkan untuk sensor TGS 2620 nilai persentase RSD yang dihasilkan tidak konstan, selalu menunjukkan perubahan yang besar pada setiap pengujian dengan rentang nilai antara 9,53\% sampai dengan 63,43\%. Hal ini dapat dikarenakan sensor TGS 2620 sensitif terhadap hidrogen yang terdapat pada lendir yang dihasilkan daging ikan. Daging ikan akan mengeluarkan lendir saat disimpan. Berdasarkan data tersebut, lendir yang dihasilkan perjamnya tidak konstan sehingga pada satu pengujian dengan pengujian lainnya akan menghasilkan nilai yang berbeda, hal ini mengakibatkan nila RSD semakin besar. 
Tabel 1 Ripitabilitas electronic nose untuk seluruh jenis sampel

\begin{tabular}{|l|c|c|c|c|c|c|}
\hline \multirow{3}{*}{ Sampel } & \multirow{2}{*}{ Waktu } & \multicolumn{5}{|c|}{ RSD \% } \\
\cline { 3 - 7 } & & $\begin{array}{c}\text { TGS } \\
2620\end{array}$ & TGS 813 & TGS 822 & TGS 2600 & TGS2602 \\
\hline \multirow{5}{*}{ Bawal } & 0 JAM & 18,45682 & 18,13352 & 23,73985 & 34,69468 & 54,93225 \\
\cline { 2 - 7 } & 5 JAM & 6,709112 & 8,618556 & 23,54588 & 6,556986 & 18,98747 \\
\cline { 2 - 7 } & 7,5 JAM & 13,51868 & 12,07041 & 10,35453 & 11,66355 & 21,79654 \\
\cline { 2 - 7 } & 10 JAM & 6,857752 & 12,82012 & 11,52031 & 6,602419 & 19,2056 \\
\cline { 2 - 7 } & 12,5 JAM & 9,36253 & 11,36718 & 11,62374 & 5,813501 & 32,45452 \\
\cline { 2 - 7 } & 24 JAM & 6,073372 & 8,740842 & 6,110119 & 5,646476 & 40,8538 \\
\hline \multirow{5}{*}{ Lele } & 0 JAM & 28,55516 & 27,90021 & 24,26319 & 28,89937 & 36,22287 \\
\cline { 2 - 7 } & 5 JAM & 29,90586 & 11,8642 & 34,94321 & 28,12932 & 9,354844 \\
\cline { 2 - 7 } & 7,5 JAM & 18,86181 & 15,86518 & 22,56515 & 23,68076 & 19,61765 \\
\cline { 2 - 7 } & 10 JAM & 19,38975 & 11,69488 & 14,80371 & 22,29838 & 29,65591 \\
\cline { 2 - 7 } & 24 JAM & 21,15896 & 14,26857 & 18,66323 & 21,13594 & 22,95689 \\
\hline \multirow{5}{*}{ Nila } & 0 JAM & 9,643712 & 17,23491 & 20,53583 & 15,32838 & 36,9647 \\
\cline { 2 - 7 } & 5 JAM & 9,592231 & 9,08899 & 16,64323 & 12,60256 & 27,10009 \\
\cline { 2 - 7 } & 7,5 JAM & 9,99975 & 8,612857 & 17,66855 & 16,80358 & 63,42995 \\
\cline { 2 - 7 } & 10 JAM & 3,24563 & 10,26047 & 4,038783 & 3,736272 & 13,19394 \\
\cline { 2 - 7 } & 24 JAM & 12,56841 & 4,492505 & 10,01331 & 17,66676 & 12,71096 \\
\hline
\end{tabular}

\section{KESIMPULAN} berikut :

Berdasarkan penelitian yang telah dilakukan maka dapat diambil kesimpulan sebagai

1. Electronic nose dapat mendeteksi pola pembusukan ikan air tawar dengan persentase variansi dua komponen utama sebesar 98,92\%.

2. Ikan bawal mulai mengeluarkan aroma tidak sedap pada pengujian 12,5 jam, lele pada pengujian 10 jam, dan nila pada pengujian 10 jam.

3. TGS 822 memberikan respon tinggi saat sampel ikan sudah dalam keadaan tidak segar dikarenakan sensor ini sensitif terhadap aroma yang ditimbulkan oleh senyawa organik.

4. Sensor TGS 2602 memberikan nilai persentase RSD yang tinggi yaitu $63,43 \%$, oleh karena itu sensor ini tidak cocok digunakan untuk pengujian pengulangan sampel ikan air tawar.

\section{SARAN}

Saran yang dapat disampaikan untuk penelitian yang akan datang :

1. Mengganti sensor TGS 2602 dan megunakan sensor yang lebih banyak sehingga kepekaan terhadap berbagai macam bau lebih tinggi.

2. Penambahan sekat antara ruang sampel dan ruang sensor, sehingga bau dari sampel tidak bocor ke ruang sensor apabila sedang dilakukan odor off.

3. Dilakukan pengolahan data dengan metode jaringan syaraf tiruan (JST) agar bisa mengklasifikasi jenis sampel yang diuji. 


\section{UCAPAN TERIMA KASIH}

Penulis mengucapkan terima kasih kepada Danang Lelono, S.Si., M.T. yang telah meminjamkan alat berupa sensor kepada penulis selama melakukan penelitian ini.

\section{DAFTAR PUSTAKA}

[1] Afrianto, E., Liviawaty, E., 1989. Pengawetan dan Pengolahan Ikan, kanisius, Yogyakarta.

[2] Neu, D., Tro, N. J., 2009. Chemistry in Focus : A Molecular View of Our World, Westmont College, Santa Barbara, USA.

[3] Lelono, D., Triyana, K., Hartati, S., Amalinda, F., Kaltsum, U., Usuman, I., 2011. Rancang Bangun Prototipe Sensor Rasa Elektronik Berbasis Membran Selektif Ion, Jurusan Ilmu Komputer dan Elektronika, FMIPA UGM, Yogyakarta.

[4] Pearce,T.C., Schiffman, S.S, Nagle, H.T., 2003, Handbook of Machine OlfactionElectronic Nose Technology, WILEY-VCH, UK.

[5] Sadeghifard, S., Esmaeilani, L., 2012, A New Embedded E-nose system to Identify Smell of Smoke, $20127^{\text {th }}$ International Conference on System of System Engineering (SoSE), Genoa. 16-19 July 2012.

[6] Widyatmoko, P.H, 2014. Rancang Bangun Electronic Nose Untuk Klasifikasi Kemurnian Minyak Tanah, Skripsi. Jurusan Ilmu Komputer Dan Elektronika, FMIPA, UGM, Yogyakarta.

[7] Rosyad, F., 2015. Klasifikasi Kemurnian Daging Sapi Berbasis Electronic Nose dengan Metode Principal Component Analysis, skripsi, Jurusan Ilmu Komputer Dan Elektronika, FMIPA UGM, Yogyakarta.

[8] Haddad, R., 2007, A Feature Extraction Algorithm for Multi-Peaks Signals in Electronic Noses, Department of Computer Science and Applied Mathematics, The Weizmann Institute of Science, Rehovot 76100, Israel.

[9] Soemartini, 2008. Principal Component Analysis (PCA) Sebagai Salah Satu Metode Untuk Mengatasi Masalah Multikonlinearitas, Skripsi, Jurusan Statistika Fakultas Matematika Dan Ilmu Pengetahuan Alam, Universitas Padjajaran, Jatinangor. 